\title{
Peran Institusi Keagamaan di Maluku dalam Upaya Pemberantasan Korupsi
}

\author{
Henky H Hetharia \\ Fakultas Teologi Universitas Kristen Indonesia Maluku \\ J1. Ot Pattimaipauw, Talake Kecamatan Nusaniwe Kota Ambon, Maluku, Indonesia \\ E-mail: sonny_hetharia@yahoo.com \\ Samuel J Mailoa \\ Fakultas Teologi Universitas Kristen Indonesia Maluku \\ Jl. Ot Pattimaipauw, Talake Kecamatan Nusaniwe Kota Ambon, Maluku, Indonesia \\ E-mail: boetjesjm@gmail.com
}

\begin{abstract}
It is an anomaly in the life of the Moluccas' society that the majority of people who committed the criminal act of corruption are considered as religious people. Besides, they are categorized as diligent, obedient and even fanatic adherent of their religions. The act of corruption is an act not only against the law but also against moral and spiritual values. This article explores the role of religious institutions in spreading moral and spiritual values to prevent Molucca's people from committing corruption. This article used a qualitative method of both: fieldwork and textual study. For fieldwork, in-depth interview and observation are used to gather data from the prisoners, officers, and workers at the prison (Lembaga Pemasyarakatan Klas IIa) in Ambon. All the data are presented using descriptive analysis. The research shows that the role, function, and accountability of religious institutions in the Moluccas are very weak in preventing and eradicating the criminal act of corruption among the prisoners and the police officers, prosecutors, judges, lawyers, and journalists who played along the criminal act of corruption. Those acts have violated their commitment to stand for justice for all people.
\end{abstract}

Keywords:

Fight against the corruption; religious institutions; the Moluccas.

\begin{abstract}
Abstrak
Suatu anomali yang terjadi dalam kehidupan masyarakat Maluku ialah adanya realitas bahwa para pelaku Tindak Pidana Korupsi (Tipikor) adalah orang-orang yang beragama, baik Islam maupun Kristen.Ironisnya, para pelaku Tipikor ini adalah orang-orang yang taat dan rajin dalam beragama seperti orang Maluku umumnya. Perbuatan Tipikor tidak hanya melanggar hukum, tetapi juga melanggar nilai-nilai moral, spiritual dan religius. Apakah institusi keagamaan di Maluku telah melaksanakan peran, fungsi dan tanggung jawab penguatan nilai-nilai moral, iman umatnya dalam upaya pemberantasan perbuatan Tipikor? Artikel ini berdasarkan hasil penelitian yang menggunakan metode kualitatif dengan teknik pengumpulan data observasi dan wawancara mendalam dengan pimpinan, petugas Lembaga Pemasyarakatan Kelas IIa (LAPAS), warga binaannya yang terkait perbuatan Tipikor, dan studi kepustakaan. Data dianalisis secara kualitatif-deskriptif mengenai peran, fungsi dan tanggung jawab institusi keagamaan di Maluku memperkuat penghayatan dan pemberlakuan nilai-nilai moral, spiritual dan religius umat, terutama kalangan para penegak hukum demi pemberantasan perbuatan Tipikor. Temuan penelitian itu memperlihatkan bahwa peran, fungsi dan tanggung jawab institusi agama sangat lemah dalam pencegahan dan pemberantasan Tipikor di kalangan warga binaan, dan oknum jaksa, polisi, pengacara, hakim, dan wartawan yang berkelindan dalam penanganan kasus Tipikor. Semangat pencegahan dan pemberantasan Tipikor dengan menjadikan jumlah kasus korupsi sebagai target tahunan oleh oknum penegak hukum, terlihat memberangus kebenaran dan keadilan itu sendiri.
\end{abstract}

Kata Kunci:

Pemberantasan korupsi; institusi keagamaan; Maluku.

DOI: $10.15575 / \mathrm{jw} . v 2 \mathrm{i} 1.921$

Received: October 2016; Accepted: June 2017; Published: June 2017 


\section{A. PENDAHULUAN}

Perbuatan tindak pidana korupsi (Tipikor) di Indonesia masih menjadi masalah sosial dan masalah hukum yang belum terselesaikan hingga saat ini, baik pada tingkat pusat maupun daerah. Tidak heran jika Transparency International (TI) dalam surveinya (10 Desember 2014), menempatkan Indonesia pada peringkat 109 dari 175 negara yang disurvei (dengan Indeks Persepsi Korupsi: 3,4). Hal itu berarti bahwa Indonesia masih tergolong sebagai kelompok negara koruptif di dunia. Praktik korupsi terjadi di pusat hingga ke daerah, termasuk di Maluku. Berdasarkan data Kejaksaan Tinggi Maluku ${ }^{1}$, selama 2009 -2014, jumlah kasus Tipikor di Maluku sebanyak 76 kasus (rata-rata 15 kasus/tahun), di mana yang beragama Islam sebanyak 30 orang, beragama Kristen sebanyak 45 orang dan beragama Hindu 1 orang. Menarik untuk dikaji bahwa mereka yang menjadi pelaku Tipikor ini adalah juga orang-orang yang taat beragama dan beribadah, bahkan fanatik dalam beragama sebagaimana orang Maluku pada umumnya. Secara sosial, mereka adalah orang-orang yang cukup terpandang di masyarakat, dan demi gengsi sosialnya tersebut, mereka juga adalah orang-orang yang rajin beribadah. Maraknya praktik Tipikor di kalangan elit pemerintahan di Maluku, pernah dilakukan oleh Hetharia, dkk. ${ }^{2}$, mengenai agama dan perilaku korupsi di Maluku. Hasil penelitian ini menyimpulkan bahwa perilaku korupsi aparat pemerintah di Maluku didorong oleh 3 faktor, yaitu: (a) kebijakan pemerintah, (b) tingkat jabatan dan (c) besarnya pendapatan.

Pada sisi lain, upaya pemberantasan korupsi di Indonesia terus menjadi salah satu agenda utama pemerintah RI melalui pencanangan Gerakkan Nasional Pemberantasan Korupsi (GNPK, 9 Desember 2004), disusul terbitnya

1 Kejaksaan Tinggi Maluku, Laporan Bulanan Tindak Pidana Korupsi: Februari 2015 (Ambon: Tidak dipublikasi, 2015).

${ }^{2}$ Henky H Hetharia, Samuel Julius Mailoa, dan Elia Radianto, Agama Dan Perilaku Korupsi Di Provinsi Maluku (Ambon: Belum dipublikasikan, 2010).
INPRES RI No. 5 Tahun 2004 tentang Percepatan Pemberantasan Korupsi, dan pembentukan lembaga Komisi Pemberantasan Korupsi (KPK) yang masih diberlakukan sampai saat ini. Upaya pemberantasan korupsi ini tidak hanya merupakan masalah hukum tetapi juga masalah moral, spiritual dan religius, sehingga dibutuhkan juga pendekatan moral, spiritual dan religius. Hal ini ditegaskan oleh Presiden RI (Susilo Bambang Yudhoyono) pada pencanangan hari GNPK, bahwa gerakan pemberantasan korupsi di Indonesia haruslah didukung juga oleh para alim ulama, tokoh agama, kaum cendekiawan, budayawan serta tokoh masyarakat lainnya sebagai gerakan moral bersama melawan perbuatan Tipikor. ${ }^{3}$ Masalah korupsi tidak hanya diatasi dengan upaya hukum (represive), tetapi juga peran institusi keagamaan dalam upaya penguatan moral (preventive).

Institusi keagamaan di Maluku, dalam hal ini Gereja Protestan Maluku (GPM) yang mewakili agama Kristen Protestan, Gereja Katholik dan Majelis Ulama Indonesia (MUI) daerah Maluku sebagai tiga institusi agama terbesar di Maluku yang mengajarkan pendidikan agama (Kristen, Katholik dan Islam) di Maluku, bertanggung jawab untuk mengatasi masalah korupsi ini, melalui penguatan moral, iman dan religius umat. Penelitian sebelumnya yang dilakukan Hetharia, dkk., ${ }^{4}$ menyimpulkan bahwa aspek ajaran agama mempunyai pengaruh negatif (menurunkan) terhadap perilaku korupsi di Maluku. Hal ini berarti bahwa perilaku korupsi sebagai masalah moral, sangat bergantung pada pembinaan oleh institusi keagamaan bagi umatnya. Karena itu permasalahan penting yang dikaji adalah "Apakah institusi keagamaan di Maluku telah melaksanakan peran, fungsi dan tanggung jawab penguatan nilai-nilai moral,

\footnotetext{
${ }^{3}$ Sekertariat Negara, "Sambutan Presiden RI Pada Pencanangan Gerakan Nasional Pemberantasan Korupsi , (Jakarta: Percetakan Negara RI, )," in Percepatan Pemberantasan Korupsi (Jakarta: Percetakan Negara RI, 2004), ix.

4 Hetharia, Mailoa, dan Radianto, Agama Dan Perilaku Korupsi Di Provinsi Maluku.
} 
iman umatnya dalam upaya pemberantasan perbuatan Tipikor?"

Penelitian ini bertujuan untuk mengetahui peran, fungsi dan tanggung jawab institusi keagamaan di Maluku dalam memperkuat penghayatan dan pemberlakuan nilai-nilai moral, spiritual dan religius di kalangan umat beragama di Maluku, dalam upaya pencegahan dan pemberantasan korupsi. Apakah institusi keagamaan di Maluku telah melaksanakan peran, fungsi dan tanggung jawabnya dalam memperkuat keimanan umatnya agar tidak melakukan korupsi (pencegahan) maupun mendampingi umatnya yang telah terlibat dalam tindak pidana korupsi (Tipikor), khususnya mereka yang telah menjadi warga binaan di LAPAS Ambon. Penelitian ini difokuskan (berlokasi) pada institusi keagamaan yang ada di Maluku (Majelis Ulama Indonesia/MUI Wilayah Maluku, Sinode Gereja Protestan Maluku/GPM, dan Keuskupan Amboina di Maluku), dan umat dari ketiga agama ini yang terkait kasus tindak pidana korupsi (Tipikor) dan menjadi warga binaan yang berada di LAPAS Kelas IIa yang berlokasi di kota Ambon.

Teknik pengumpulan data melalui wawancara dengan warga binaan kasus Tipikor di LAPAS Ambon, dimaksudkan untuk mendapatkan informasi yang benarbenar akurat, yaitu yang menggambarkan informasi yang sebenarnya mengenai permasalahan yang diteliti, yaitu tentang peranan institusi keagamaan di Maluku dalam upaya pemberantasan korupsi. Validitas dan realibilitas instrumen dilakukan dengan mengecek secara silang (cross check) keterangan yang diperoleh dari sumber yang berbeda, yaitu informasi dari sumber informan, sumber peristiwa dan tempat serta informasi yang dikumpulkan dari sumber dokumen/literatur dan kepustakaan.Teknik analisis data dilakukan secara induktif dengan menggunakan model Miles dan Huberman, yaitu dengan mereduksi data yang telah terkumpul sesuai fokus penelitian. Selanjutnya, data yang telah direduksi itu disajikan. Akhirnya, data yang telah disajikan itu diverifikasi, dianalisis dan disimpulkan. ${ }^{5}$

Penelitian dilakukan pada bulan Mei s/d Juli 2016. Menurut Kepala Lapas Kelas IIa Ambon, "Populasi warga binaan kasus Tipikor adalah berjumlah 58 orang, dengan perincian: 18 orang beragama Islam, 32 orang beragama Kristen Protestan, dan 8 orang Kristen Katolik." Dari 58 warga binaan ini, penulis berhasil mewawancarai 19 orang warga binaan (informan kunci), dengan perincian: 5 orang beragama Islam, 12 orang beragama Kristen Protestan, dan 2 orang beragama Kristen Katolik. Ke-19 orang warga binaan yang telah diwawancarai ini, dipandang telah mewakili unsur agama (Kristen, Katholik dan Islam), ketersebaran wilayah di provinsi Maluku (Kota Ambon, Kabupaten Maluku Tengah, Seram Bagian Barat, Seram Bagian Timur, Buru Selatan, Maluku Tenggara, Kepulauan Aru, Maluku Tenggara Barat dan Maluku Barat Daya) dan provinsi Maluku Utara (Kepulauan Sula), yang terdiri dari berbagai kalangan: birokrasi, anggota dewan, pengusaha/kontraktor, dan profesi lainnya.

\section{B. HASIL DAN PEMBAHASAN \\ 1. Korupsi dan Peran Institusi Keagamaan}

Istilah korupsi berasal dari kata Latin corruptio yang berarti: hal merusak atau hal membuat busuk, pembusukan, penyuapan. Kata Latin ini kemudian digunakan dalam bahasa Inggris (corruption), bahasa Belanda (corruptie), dan selanjutnya dalam bahasa Indonesia (korupsi). Dalam Kamus Besar Bahasa Indonesia, ${ }^{7}$ kata korup (kata sifat) berarti: buruk, rusak, busuk, suap; atau suka memakai barang (uang) yang dipercayakan kepadanya, dapat disogok (memakai kekuasaannya untuk kepentingan pribadi). Sedangkan korupsi (kata benda) berarti: penye-

\footnotetext{
${ }^{5}$ Bd Sugiyono, Memahami Penelitian Kualitatif (Bdanung: Alfabeta, 2009), 91-99.

${ }^{6}$ S. Anwar, (Kepala LAPAS Kelas II a), wawancara oleh Henky H Hetharia, Kantor LAPAS Kelas II a Ambon, tanggal 21 Mei 2016 pukul 09.00 WIT

${ }^{7}$ Departemen Pendidikan Nasional, Kamus Besar Bahasa Indonesia (Jakarta: Balai Pustaka, 2005), 596.
} 
lewengan atau penyalahgunaan uang Negara, perusahaan dan sebagainya untuk kepentingan pribadi atau orang lain. Klitgaard $^{8}$ menilai bahwa kata Latin corruptio ini, menimbulkan serangkaian gambaran yang jahat; kata ini berarti apa saja yang merusak keutuhan, ada nada moral pada kata tersebut. Definisi korupsi juga telah diatur dalam UndangUndang RI nomor 31 tahun 1999 tentang Pemberantasan Tindak Pidana Korupsi (psl. 2 ay. 1), yaitu:

Setiap orang yang secara melawan hukum melakukan perbuatan memperkaya diri sendiri atau orang lain atau suatu korporasi yang dapat merugikan keuangan negara atau perekonomian negara ...

Alatas 9 membagi tujuh jenis korupsi berdasarkan tipologinya, yaitu: korupsi transaktif (trans-active corruption), korupsi yang memeras (extortive corruption), korupsi investif (investive corruption), korupsi perkerabatan (nepotistic corruption), korupsi defensif (defensive corruption), korupsi otogenik (autogenic corruption), korupsi dukungan (supportive corruption). Anwary ${ }^{10}$ menyebutkan modus operandi korupsi, yaitu: manipulasi, penggelapan, penyuapan, pemerasan, pungutan liar (pungli), penjarahan atas harta kekayaan negara, pencurian uang negara melalui Anggaran Pendapatan dan Belanja Negara (APBN) dan Anggaran Pendapatan dan Belanja Daerah (APBD), korupsi pembangunan sarana fisik atau infrastruktur baik yang dibiayai oleh pinjaman luar negeri, APBN maupun APBD.

Wang An Shih (1021 - 1086), seorang negarawan Cina, menegaskan adanya dua sumber korupsi, yakni: buruknya hukum dan buruknya orang. Karena itu, ia mengajukan dua syarat mutlak melawan korupsi yaitu: para pemegang kekuasaan yang bermoral tinggi dan hukum yang efisien serta rasional. Kedua

\footnotetext{
${ }^{8}$ Robert Klitgaard, Membasmi Korupsi (Jakarta: Yayasan Obor Indonesia, 2001), 31.

${ }^{9}$ Alatas, Korupsi, Sifat, Sebab Dan Fungsi (Jakarta: LP3ES, 1987), ix.

${ }^{10}$ S. Anwary, Quo Vadis Pemberantasan Korupsi Di Indonesia (Jakarta: ISEPS-AMRA, 2005), 9-12.
}

sumber korupsi yang disebutkan Wang An Shih di atas senantiasa muncul berulang-ulang dalam perjalanan sejarah bangsa bangsa di zaman dulu hingga sekarang ini. ${ }^{11}$ Klitgaard $^{12}$ mengemukakan rumus penyebab korupsi: $\mathbf{C}=$ $\mathbf{M}+\mathbf{D}$ - A, di mana: Corruption (C) [Korupsi] sama dengan Monopoly power (M) [kekuasaan monopoli] plus Discretion by officials (D) [wewenang pejabat] minus Accountability (A) [akuntabilitas]. Rumus ini menjelaskan bahwa jika seseorang memegang monopoli atas barang atau jasa dan memiliki wewenang untuk memutuskan siapa yang berhak mendapat barang atau jasa itu dan berapa banyak, dan tidak ada akuntabilitas, maka kemungkinan besar akan ditemukan korupsi di situ.

Agama sebagai institusi moral dan spiritual bertanggung jawab untuk membentuk moral manusia. Baik dan buruknya moral manusia, sangat dipengaruhi oleh sejauh mana institusi keagamaan mengajarkan nilai-nilai moral agamanya kepada umatnya masing-masing. Wijayanto $^{13}$ mengatakan bahwa agama dan pendidikan agama memegang peranan penting dalam memerangi korupsi, mengingat korupsi merupakan refleksi dari lemahnya integritas individu, dan agama serta pendidikan agama berorientasi mencetak manusia-manusia berhati mulia dan bermoral tinggi.

Robert Borrong ${ }^{14}$ menegaskan bahwa semua agama mengajarkan bahwa korupsi adalah tindakan tercela, baik dari sudut pandang cara (means) maupun dari sudut pandang akibat dan tujuannya (ends). Bangsa Indonesia dikenal sebagai bangsa yang religius (kental beragama) namun masih tergolong sebagai negara terkorupsi di dunia. Kenyataan ini merupakan suatu ironi bagi kehidupan religius tadi. Itu berarti ada sesuatu yang tidak pas (missing) dalam kehidupan

\footnotetext{
${ }^{11}$ Alatas, Sosiologi Korupsi (Jakarta: LP3ES, 1981), 58.

${ }^{12}$ Klitgaard, Membasmi Korupsi, 62.

${ }^{13}$ Wijayanto dan Zachrie Ridwan, eds., Korupsi Mengkorupsi Indonesia (Jakarta: PT Gramedia Pustaka Utama, 2009), 65.

${ }^{14}$ Robert Borrong, Etika Politik Kristen (Jakarta: UPI STT Jakarta, 2006), 34.
} 
beragama di Indonesia.Yang tidak pas itu adalah bahwa agama dipahami sebagai sejumlah aturan dan upacara tetapi tidak diterjemahkan ke dalam kehidupan bermoral. Nilai-nilai agama belum menjiwai atau belum menjadi karakter dalam berperilaku. Adanya kesadaran umum dalam masyarakat akan korupsi sebagai perbuatan tercela merupakan peluang bagi para pemimpin agama dan institusi keagamaan untuk menggalang kerja sama menyebarluaskan gerakan moral yang sekarang ini sedang diprakarsai oleh para pemimpin umat beragama di Indonesia untuk menjadi gerakan umat dan masyarakat.

Azyumardi Azra ${ }^{15}$ menegaskan bahwa jika agama ingin berperan lebih besar dalam pemberantasan korupsi, maka agama harus meningkatkan peran institusi keagamaan. Lembaga-lembaga pengurus masjid atau gereja, dan organisasi sosial keagamaan seperti NU, Muhammadiyah, dan lain-lain memiliki kredibilitas tertinggi dibandingkan lembagalembaga lain untuk mencegah kemungkinan terjadinya korupsi dan penyelewengan lainnya. Oleh sebab itu, lembaga-lembaga keagamaan tersebut seharusnya lebih berani dan lantang memproklamasikan perang melawan korupsi disertai konsistensi dan aksi sistematik dalam pencegahan dan pemberantasan korupsi.

Hasil penelitian yang telah dilakukan oleh Hetharia, dkk., ${ }^{16}$ mengenai 'agama dan perilaku korupsi di Maluku, menyimpulkan bahwa perilaku korupsi aparat pemerintah daerah di provinsi Maluku didorong oleh 3 faktor, yaitu: (a) kebijakan pemerintah, (b) tingkat jabatan dan (c) besarnya pendapatan. Ketiga faktor ini mempunyai pengaruh positif (meningkatkan) terhadap perilaku korupsi, yaitu jika kebijakan pemerintah meningkat 1 $\%$, akan menyebabkan perilaku korupsi meningkat 0,475 ; jika tingkat jabatan meningkat $1 \%$, akan menyebabkan perilaku korupsi meningkat sebesar $1,40 \%$; dan jika

\footnotetext{
${ }^{15}$ Wijayanto dan Ridwan, Korupsi Mengkorupsi Indonesia, 839.

${ }^{16}$ Hetharia, Mailoa, dan Radianto, Agama Dan Perilaku Korupsi Di Provinsi Maluku.
}

pendapatan meningkat $1 \%$, akan menyebabkan perilaku korupsi meningkat sebesar $0,56 \%$. Pada sisi lain, penelitian itu juga menyimpulkan bahwa aspek ajaran agama mempunyai pengaruh negatif (menurunkan) terhadap perilaku korupsi di Maluku, yaitu apabila terjadi peningkatan ajaran agama sebesar $1 \%$, maka akan menyebabkan perilaku korupsi menurun sebesar $0,33 \%$.

Penelitian ini dilakukan di Ambon, sebab tidak ada orang di daerah lain, yang mudah tersulut konflik karena alasan mempertahankan eksistensi agamanya bila dibandingkan dengan orang Maluku, seperti yang pernah terjadi yaitu konflik social keagamaan antara tahun 1999 sampai 2004 yang menimbulkan trauma yang dalam sampai saat ini $^{17}$. Hal ini memperlihatkan bahwa kehidupan beragama di kalangan orang Maluku sangat kental. Kekhususan orang Maluku pelaku Tipikor bila dibandingkan dengan yang lain adalah secara sosial, pelaku Tipikor adalah orang-orang yang cukup terpandang di masyarakat. Mereka juga adalah orang-orang yang rajin menjalankan ajaran dan syariah agamanya demi gengsi sosial tersebut. Selain itu, kekhususan orang Maluku adalah ketaatan (loyalitas) habis-habisan bahkan rela berkorban kepada pimpinan atau atasan di lembaga tempat mereka bekerja. Sikap loyalitas orang Maluku inilah yang menyebabkan banyak orang Maluku didayagunakan secara salah oleh Pemerintah Kolonial Belanda sebagai pasukan KNIL yang memerangi sesama bangsa Indonesianya sendiri. Mengacu pada temuan dan kesimpulan penelitian tersebut, maka dapat ditarik benang merah bahwa kajian peran institusi keagamaan (MUI, GPM, dan Keuskupan) dalam melaksanakan fungsi dan tanggung jawabnya untuk penguatan ajaran agama (Kristen, Katholik dan Islam) dalam mencegah perbuatanTipikor di Maluku menjadi amat urgen. Jika peran, fungsi dan

\footnotetext{
17 Yance Zadrak Rumahuru, "Socio-Religious Movement of Religious Affiliated Student Organizations After Social Conflict in Ambon," AlAlbab 5, no. 2 (2016): 261.
} 
tanggung jawab institusi keagamaan tersebut ditingkatkan, maka akan menurunkan perilaku dan praktik Tipikor di Maluku.

Institusi-institusi keagamaan di Maluku, memiliki tanggung jawab bersama pemerintah dalam upaya pencegahan dan pemberantasan tindak pidana korupsi, sebab korupsi bukan hanya masalah hukum atau masalah sosial yang menjadi domain pemerintah, tetapi juga masalah moral-etik yang menjadi domain dan tanggung jawab agama dalam membina umatnya. Agama-agama khususnya di Maluku, walaupun berbeda-beda namun memiliki tanggung jawab moral yang sama dalam membina kehidupan moral dan rohani umatnya untuk menjadi warga negara Indonesia yang baik dan bertanggung jawab, termasuk tidak melakukan korupsi. Casram ${ }^{18}$ mengutip Schuon, mengatakan bahwa agama secara eksoteris terlahir di dunia ini berbeda-beda. Akan tetapi terlepas dari perbedaan yang muncul dalam agamaagama, secara esoterik agama-agama yang ada di dunia memiliki prinsip yang sama, yaitu bersumber dan tertuju pada Supreme Being. Casram lebih lanjut menjelaskan bahwa cara Schuon membedakan kedua aspek agama ini bisa diterapkan sebagai panduan bagi manusia yang berbeda agama untuk bertemu satu sama lain dalam memberikan peran mereka sebagai hamba Tuhan Yang Maha Esa di dunia ini. Salah satu peran agama-agama yang berbeda tersebut adalah membantu pemerintah dalam melaksanakan fungsi dan perannya dalam mencegah dan memberantas perbuatan Tipikor.

\section{Peran, Fungsi dan Tanggungjawab Institusi Agama mencegah perbuatan Tipikor}

Hasil wawancara dengan para warga binaan kasus Tipikor yang beragama Kristen Protestan terungkap bahwa selama hidup mereka tidak mengalami sentuhan pembinaan dan pendidikan agama dari tokoh-tokoh agama Kristen mengenai pengertian perbuatan Tipi-

\footnotetext{
${ }^{18}$ Casram Casram, "Membangun Sikap Toleransi Beragama Dalam Masyarakat Plural," Wawasan: Jurnal Ilmiah Agama Dan Sosial Budaya 1, no. 2 (2016): 188.
}

kor dengan segala akibatnya apalagi yang direfleksikan dalam terang pengajaran kitab suci (Alkitab). Menurut Ibu E.M., "Saya tidak pernah mendengar dan mengetahui pandangan ajaran tentang perbuatan Tipikor di dalam agama saya, selain dari pada penyampaian secara umum aturan-aturan mengenai perbuatan 'jangan mencuri' yang disampaikan oleh pimpinan agama." Selanjutnya, ia menambahkan bahwa dia juga tidak menemukan ajaran tentang perbuatan Tipikor yang harus dilawan dalam buku-buku agama yang pernah dibacanya. Menurut beliau juga bahwa beliau kurang ada pengajaran atau nasihat dalam rangka mengeliminasi perbuatan Tipikor yang diprogramkan oleh institusi agama secara spesifik dan terinci mengenai apa, mengapa, bagaimana dan akibat perbuatan Tipikor dan larangan untuk melakukan perbuatan itu. ${ }^{19}$ Pendapat Ibu E.M. ini juga sama seperti yang dikemukakan oleh Ibu Y.P., ${ }^{20}$, L.B, ${ }^{21}$ Edm.S., ${ }^{22}$ dan F.M. ${ }^{23}$

Dalam hal ini, pengajaran atau nasihat gereja sebagai institusi agama dalam berbagai kesempatan (Ibadah Minggu, Ibadah Kaum Lelaki, Ibadah Kaum Perempuan, Ibadah Unit Keluarga) kepada mereka terkadang disam-

${ }^{19}$ E.M (Warga Binaan, kasus Tipikor APBD Hukuman Inkraag 1,2 Tahun), wawancara oleh Henky H Hetharia, Kantor LAPAS Kelas II a di Ambon, tanggal 21 Mei 2016 pukul 11.00 WIT.

${ }^{20}$ Y.P (Warga Binaan, kasus Tipikor Jaminan Kesehatan Masyarakat Tahun 2014 - Hukuman Inkraag 1,2 Tahun), wawancara oleh Henky H Hetharia, Kantor LAPAS Kelas II a Ambon, tanggal 23 Mei 2016 pukul 12.00 WIT.

${ }^{21}$ L.B (Warga Binaan, kasus Tipikor Uang Untuk dipertanggungjawabkan Provinsi Maluku - Hukuman Inkraag 5 Tahun), wawancara oleh Henky H Hetharia, Kantor LAPAS Kelas II a Ambon, tanggal 21 Mei 2016 pukul 11.00 WIT.

${ }^{22}$ Edm. S (Warga Binaan, kasus Tipikor Pengadaan perlengkapan alat-alat penerangan/lampu jalan dalam rangka MTQ Nasional 2012 di Ambon-Hukuman Inkraag 1 Tahun), wawancara oleh Henky H Hetharia, Kantor LAPAS Kelas II a Ambon, tanggal 18 Juni 2016 pukul 14.00 WIT.

${ }^{23}$ F.M (Warga Binaan, kasus Tipikor Perjalanan Dinas Fiktif. - Hukuman Inkraag 2 Tahun), wawancara oleh Henky H Hetharia, Kantor LAPAS Kelas II a Ambon, tanggal 11 Juni 2016 pukul 11.00 WIT. 
paikan secara umum oleh tokoh-tokoh agama (pendeta, anggota majelis jemaat dan aktivis gereja lainnya) dalam bentuk khotbah, telaahan kitab suci, diskusi, meditasi dan ceramah sesungguhnya tidak secara spesifik dan rinci menguraikan apa, mengapa, bagaimana dan akibat dari perbuatan Tipikor tersebut. Uraian lebih banyak pada aspek "jangan mencuri" yang dipersepsikan mereka adalah larangan mencuri di rumah atau gedung perkantoran. Mereka baru mengerti sesuatu perbuatan diklasifikasikan sebagai perbuatan Tipikor ketika mereka mengalami pemeriksaan oleh petugas kejaksaan dan/atau kepolisian, diskusi dengan pengacara dan menjalani proses hukum di pengadilan. Tentang hal ini, menurut Ibu F.L mengatakan bahwa dia baru mengerti apa itu Tipikor, ketika beliau divonis melakukan perbuatan Tipikor. Awalnya dia mengira kesalahan atau ketidakcermatan dalam melakukan tugas administratif keuangan belum dapat diklasifikasikan sebagai perbuatan Tipikor, karena. ${ }^{24}$ Pendapat yang sama dengan Ibu F.L. ini juga dikemukakan oleh Ibu D de Q dan Bapak N.H. ${ }^{25}$ Ada di antara mereka yang terjerat kasus Tipikor, karena mereka mengerjakan apa yang diperintahkan oleh atasan langsung ataupun the big boss.

Ketaatan kepada perintah atasan ini mereka lakukan karena mereka menyadari hubungan di antara ketaatan, loyalitas mereka dengan kewajiban mereka sebagai Aparatur Sipil Negara. Malahan ada di antara mereka dari kalangan birokrasi dan pengusaha/kontraktor yang tidak mengerti mengapa dirinya dijatuhi

\footnotetext{
${ }^{24}$ F.L (Warga Binaan kasus Tipikor Pencatatan Uang Masuk dan Keluar Anggaran Belanja Kebutuhan Pemilihan Umum Kepala Daerah Kota Ambon Tahun 2011 yang tidak dapat dipertanggungjawabkan pada Tahun 2012. Putusan Inkraag pada tahun 2015, Hukuman - 1, 2 tahun), wawancara oleh Henky $\mathrm{H}$ Hetharia, Kantor LAPAS Kelas II a Ambon, tanggal 23 Mei 2016 pukul 10.00 WIT.

${ }^{25}$ N.H (Warga Binaan, kasus Tipikor Penggunaan Dana BOS dan Dana TIK. - Hukuman Inkraag 1,5 Tahun), wawancara oleh Henky H Hetharia, Kantor LAPAS Kelas II a Ambon, tanggal 18 Mei 2016 pukul 12.00 WIT.
}

vonis memenuhi unsur perbuatan Tipikor, sementara seluruh proyek yang mereka tangani sudah dinyatakan selesai, lengkap dan sesuai dengan petunjuk teknis yang di-SK-kan oleh Bupati. Selain itu, ada di antara mereka yang telah mempresentasikan laporan proyeknya di tingkat pusat dan dinyatakan sebagai model pelaksanaan dana block grant untuk diberlakukan di seluruh Indonesia, namun tetap dinyatakan bersalah. Hal ini, dikemukakan oleh Bapak A.T.,

Saya divonis, dengan dakwaan melakukan perbuatan Tipikor Dana Block Grant dari pemerintah pusat sebesar Rp. 9 milyar. Padahal seluruh proyek penyerahan bantuan telah saya laksanakan dan tanda terima yang telah ditandatangani di atas meterai telah dibuat oleh semua Kepala Sekolah. Sedangkan Biaya Pengawasan sesuai Petunjuk Teknis saya serahkan kepada perajurit TNI yang bertugas di pulau-pulau terdepan sebagai penjaga perbatasan Indonesia. Merekalah yang menyerahkan langsung kepada semua Kepala Sekolah. Saya dipersalahkan secara administrasi. Padahal dana disetor kepada Kepala Seksi Perencanaan. Hasil pemeriksaan terdapat kelebihan volume perbantuan ke sekolah-sekolah yang seharusnya sangat menguntungkan lembaga persekolahan. Saya sendiri tidak menemukan adanya kesalahan administrasi maupun kerugian material. Malahan saya telah mempresentasikan laporan ke Pusat dan Proyek ini di Kabupaten Maluku Barat Daya menjadi model pelaksanaan bagi seluruh Indonesia." 26

Hal yang sama juga dikemukakan oleh Bapak H.O., yang menyatakan bahwa dia dan teman-teman sesama anggota DPRD Kabupaten Maluku Tenggara tidak melakukan Tipikor terhadap dana asuransi tersebut. Sebab

\footnotetext{
${ }^{26}$ A.T (Warga Binaan, kasus Tipikor Pemanfaatan Dana Block Grant dalam bidang pendidikan dari Kemendiknas - Hukuman Inkraag 2 Tahun dan 10 Bulan), wawancara oleh Henky H Hetharia, Kantor LAPAS Kelas II a Ambon, tangga Sabtu, 28 Mei 2016 pukul 14.00 WIT.
} 
mereka menilai dana asuransi adalah sah ditetapkan bersama dengan Pemerintah Daerah Kabupaten, dan memiliki legitimasi hukum sesuai PP No 110. Anehnya, ada sebagian anggota yang tidak dihukum, padahal kami semua menerima dana asuransi tersebut. ${ }^{27}$ Dalam situasi ini, mereka merasakan bahwa mereka tidak melakukan perbuatan memperkaya diri sendiri atau orang lain dengan menyalahgunakan jabatan/wewenang mereka, dan yang mengakibatkan adanya kerugian Negara.

Seluruh informan kunci menyatakan bahwa mereka kurang dibekali dengan buku-buku atau berbagai informasi secara spesifik mengenai hubungan ajaran agama mereka dengan perbuatan Tipikor dari pihak institusi agama mereka. Lebih banyak yang disampaikan oleh tokoh-tokoh agama Kristen adalah berhati-hati dalam melaksanakan kegiatan proyek pembangunan.

Dalam hal ini, terlihat adanya suatu keniscayaan bagi institusi agama untuk berperan, berfungsi dan bertanggung jawab melakukan reinterpretasi terhadap teks-teks kitab suci. Misalnya terhadap pengertian mencuri, suap, mengambil milik orang lain, dsbnya di dalam situasi baru yang dihadapi pada masa kini sehubungan dengan pengertian perbuatan Tipikor atau UU Pemberantasan Korupsi. Reinterpretasi ini sangat bermanfaat bagi umat beragama Kristen untuk mengerti standar-standar nilai yang berkaitan dengan "mencuri, suap, mengambil milik orang lain," dan sebagainya. Sebab di antara para informan kunci ini, ada yang merasa tidak mencuri, melainkan mengerjakan perintah atasan, tidak melakukan penyuapan dan tidak mengambil milik siapapun. Padahal peran, fungsi dan tanggung jawab institusi agama untuk mengajar dan mendidik umat mengenai ukuran sebuah ketaatan, tindakan penyuapan dan pengambilan milik orang lain, baik yang

\footnotetext{
${ }^{27}$ H.O (Warga Binaan, kasus Tipikor Dana Asuransi Anggota DPRD Kabupaten Maluku Tenggara Hukuman Inkraag 1,6 Tahun), wawancara oleh Henky H Hetharia, Kantor LAPAS Kelas II a Ambon, tanggal 23 Mei 2016 pukul 14.00 WIT.
}

berdampak personal maupun massal terhadap kehidupan semua orang. Selain itu, peran, fungsi dan tanggung jawab institusi agama Kristen Protestan tidak terlihat terhadap para oknum petugas kepolisian, kejaksaan, BPK/BPKP, pengacara, hakim, dan wartawan yang berkelindan membangun opini publik untuk memvonis seseorang memenuhi unsur perbuatan Tipikor. Sehingga dalam proses peradilan, seseorang dapat dengan mudah divonis berbuat Tipikor tanpa bukti-bukti yang kuat. Tentang proses peradilan seperti ini, menurut Bapak A.T., "Sampai saat ini, saya tidak mengetahui unsur-unsur apakah yang telah terpenuhi untuk diri saya sehingga dijatuhkan vonis dua tahun sepuluh bulan." Pengalaman ini juga dialami oleh Ibu D. de Q., H.S, ${ }^{28}$ dan Bapak E.S. Malahan dengan tanpa rasa malu, ada oknum petugas yang meminta uang apabila informan kunci ini menghendaki keringanan hukuman. Namun belajar dari pengalaman mereka yang memiliki pengalaman serupa, informan kunci ini menolak permintaan tersebut. Tentang hal ini, Ibu D. de Q., menyatakan bahwa selama proses peradilan, beberapa kali oknum kepolisian, kejaksaan dan hakim memintakan uang sebesar Rp. 200 juta agar vonis dapat diringankan ${ }^{29}$ Hal yang sama dikemukakan oleh Bapak E.S yang diminta untuk membayar hakim agar proses hukum dapat dipercepat, namun dia menolak. Karena merasakan bahwa proses dan hasil pekerjaan yang dicapai telah sesuai dengan isi kontrak yang ditandatangani." 30

\footnotetext{
${ }^{28}$ A.T (Warga Binaan, kasus Tipikor Pengadaan alatalat kesehatan Laboratorium Provinsi. Maluku Hukuman Inkraag 3 Tahun), wawancara oleh Henky H Hetharia, Kantor LAPAS Kelas II a Ambon, tanggal 30 Mei 2016 pukul 14.00 WIT.

${ }^{29}$ D. De Q (Warga Binaan, kasus Tipikor Proyek Pembangunan Mesjid Raya di Sanana - Hukuman Inkraag 4 Tahun), wawancara oleh Henky H Hetharia, Kantor LAPAS Kelas II a Ambon, tanggal 18 Juni 2016 pukul 14.00 WIT.

${ }^{30}$ E.S (Warga Binaan, kasus Tipikor Pengadaan Buku Perpustakaan Sekolah sesuai Dana Alokasi Khusus Tahun 2010 Kabupaten Maluku Tenggara Barat - Hukuman Inkraag 2,8 Tahun denda Rp.200 juta
} 
Hal yang sama juga dikemukakan di dalam hasil wawancara dengan para warga binaan kasus Tipikor yang beragama Kristen Katholik. Menurut Bapak F.B.,

Saya tidak pernah mendengar secara spesifik dan rinci mengenai perbuatan Tipikor dalam ajaran agama saya. Yang saya peroleh hanyalah nasihat oleh pemimpin agama saya secara umum dalam ibadah yang dapat menolong saya menyadari tindakan yang salah, namun tidak fokus pada masalah korupsi. ${ }^{31}$

Hal yang sama juga dikemukakan oleh Ibu A.H.M.,

Saya tidak pernah mendengar dan mengetahui secara mendalam dan meluas pandangan ajaran tentang perbuatan Tipikor di dalam agama saya, selain dari pada penyampaian secara umum aturan-aturan mengenai perbuatan mencuri yang disampaikan oleh pimpinan agama ketika saya mengikuti ibadah (misa) di gereja." 32

Dari kedua informan kunci terungkap bahwa dalam ajaran agama Kristen Katholik mereka tidak pernah memperoleh sosialisasi, pembinaan, pengajaran dan pendidikan secara spesifik mengenai pemberantasan korupsi sebagaimana diatur dalam peraturan perundang-undangan negara dalam perspektif iman Katholik. Namun mereka hanya memahami bahwa perbuatan Tipikor adalah berlawanan dengan dan dilarang oleh ajaran iman Katholik. Namun standar nilai mengenai yang mana diklasifikasikan sebagai perbuatan Tipikor dan mana yang bukan atau tidak

subsider 4 bulan penjara), wawancara oleh Henky $\mathrm{H}$ Hetharia, Kantor LAPAS Kelas II a Ambon, tanggal 28 Mei 2016 pukul 14.00 WIT.

${ }^{31}$ F.B (Warga Binaan, kasus Tipikor Biaya Sertifikat Prona di Kabupaten Maluku Tenggara Barat, Hukuman Inkraag 1 Tahun), wawancara oleh Henky H Hetharia, Kantor LAPAS Kelas II a Ambon, tanggal 11 Juni 2016 pukul 14.00 WIT.

${ }^{32}$ A.H.H (Warga Binaan kasus Tipikor Penggelapan Uang Pajak Nasabah - Hukuman Inkraag 11 Tahun), wawancara oleh Henky H Hetharia, Kantor LAPAS Kelas II a Ambon, tanggal 18 Juni 2016 pukul 14.00 WIT. masuk dalam klasifikasi perbuatan Tipikor tidak pernah mereka peroleh dari tokoh-tokoh agama Kristen Katholik seperti pastor, frater dan zuster. Sebab dalam proses hukum yang mereka jalani baik dalam pemeriksaan jaksa dan peradilan, petugas kejaksaan tidak memberikan bukti-bukti yang kuat mengenai perbuatan Tipikor yang mereka lakukan.

Hasil wawancara dengan informan kunci dari kalangan warga binaan yang beragama Islam diperoleh data bahwa peran, fungsi dan tanggung jawab institusi agama Islam untuk mencegah perbuatan Tipikor tidak secara spesifik. Umumnya, para da'I atau ulama membahasnya dalam kaitan dengan penegakan amar ma'ruf nahy mungkar. Sebelum masuk LAPAS, menurut informan kunci, institusi agama Islam di Maluku belum punya program nyata untuk membina atau mengarahkan umatnya agar terhindar dari perbuatan korupsi. Kalau pun ada dalam bentuk ceramah yang lebih bersifat pribadi. Tentang hal ini Bapak J.K., menyatakan

Saya pernah mendengar ceramah atau dakwah tentang larangan mencuri, baik di masjid saat khutbah Jum'at, ceramah pada saat bulan Ramdhan, dan mengikuti ceramah agama Islam di televisi. Selain itu membaca buku-buku agama Islam. Tetapi hampir tidak ada yang menulis secara langsung tentang korupsi. Hanya ada tentang pencuri dan hukumannya potong tangan. Saya belum membaca buku-buku agama Islam yang membahas korupsi secara terperinci, kecuali buku Quraish Shihab dan bukunya Anthony Salim tentang Ekonomi Islam. Lebih banyak pembahasan berkaitan dengan hal "mencuri" dan akibat hukumannya. Sebab hal itu adalah dosa besar dan tidak akan selamat dari azab sengsara." 33

\footnotetext{
${ }^{33}$ J.K (Warga Binaan kasus Tipikor Dana Tapal Batas antara Kabupaten Seram Bagian Barat dan Maluku Tengah), wawancara oleh Henky H Hetharia, Kantor LAPAS Kelas II a Ambon, tanggal 21 Mei 2016 pukul 14.00 WIT.
} 
Pendapat yang sama juga dikemukakan oleh Bapak M.L., ${ }^{34}$ A.W., ${ }^{35}$ H.T., ${ }^{36}$ dan I.T. ${ }^{37}$ Sehingga proses pembinaan untuk pencegahan perbuatan Tipikor belum berlangsung dengan baik dan strategis. Namun semua informan kunci mengetahui bahwa perbuatan Tipikor dilarang keras oleh Al-Quran dan Hadis Nabi Muhammad SAW. Malahan tidak tanggungtanggung, dalam ajaran agama Islam, pelakunya dapat dikenakan hukuman potong tangannya.

Selain itu, dari buku-buku Islam, artikel dan mendengar ceramah dan khotbah Jum'at dalam kegiatan dakwah di masjid, majelis ta'lim, TV, UU Tipikor, dan PP, Surat Kabar, uraian para pakar hukum, diskusi-diskusi pada waktu masih kuliah, dan internet yang dilakukan oleh para ustadz atau alim ulama, namun masih bersifat sangat umum dan lebih bersifat insidental. Dalam artian, hanya untuk meningkatkan iman dan taqwa kepada Allah SWT dengan menjauhkan diri dari perbuatan tercela, dosa, termasuk perbuatan Tipikor. Ada juga ajaran orang tua yang melarang dengan sangat untuk mengambil hak orang lain.

Dari pendapat para informan kunci, dapat dianalisis bahwa pengertian mereka mengenai korupsi diidentikkan dengan "mencuri" atau "mengambil barang milik orang lain" dan "menggelapkan" yang memperkaya diri sendiri, dan memperkaya orang lain yang

34 M.L (Warga Binaan, kasus Tipikor SPPD Hukuman Inkraag 2,8 Tahun), wawancara oleh Henky H Hetharia, Kantor LAPAS Kelas II a Ambon, tanggal 232016 pukul 12.00 WIT.

${ }^{35}$ A.W (Warga Binaan, kasus Tipikor Dana Transportasi dan Akomodasi MTQ Tingkat Provinsi di Kabupaten Aru, 201.- Hukuman Inkraag 1,5 Tahun), wawancara oleh Henky H Hetharia, Kantor LAPAS Kelas II a Ambon, tanggal 20 Mei 2016 pukul 10.00 WIT.

${ }^{36}$ H.T (Warga Binaan, kasus Tipikor Dana Proyek di Politeknik Kesehatan), Wawancara oleh Henky H Hetharia, Kantor LAPAS Kelas II a Ambon, tanggal 30 Mei 2016 pukul 10.00 WIT.

${ }^{37}$ I.T (Warga Binaan, kasus Tipikor Dana Pengadaan Barang pada Dinas DPRD Kabupaten Seram Bagian Timur pada tahun anggaran 2011 - Hukuman Inkraag 1,7 Tahun), wawancara oleh Henky H Hetharia, Kantor LAPAS Kelas II a Ambon, tanggal 20 Juni 2016 pukul 10.00 WIT. mengakibatkan kerugian keuangan negara dan/atau daerah. Berdasarkan pengertian ini, para informan merasakan bahwa proses peradilan yang mereka jalani sesungguhnya tidak adil. Sebab tidak ada bukti-bukti yang kuat untuk menjadi alasan mereka dikenakan UU Tipikor. Sebab mereka hanya melakukan perintah atasan.

Data yang dideskripsikan ini memperlihatkan bahwa seluruh pelaksanaan tugas mereka didasarkan atas petunjuk teknis yang jelas dan wujud sikap loyal sebagai ASN dengan melakukan perintah dari sang atasan secara lisan dan tulisan. Namun hukuman tetap dijalani mereka. Dalam hal ini, tidak semua mereka berani untuk menggunakan hak kewarnegaraannya untuk mendapatkan keadilan melalui Pengadilan Tinggi dan Mahkamah Agung. Pengalaman membuktikan kepada mereka bahwa ketika ada yang menempuh upaya banding atau kasasi guna memperoleh keadilan, harga diri dan marwahnya, maka justeru vonis yang diterimanya bertambah berat. Hal itu dinyatakan oleh Bapak H.T., "Saya mendapatkan pemberatan hukuman dari 1,2 tahun menjadi 1,5 tahun ketika menempuh upaya banding." Demikian pula yang dialami oleh Bapak A.W. Ia menyatakan "Vonis saya bertambah berat dari 1 tahun menjadi 1,5 tahun karena jaksa naik banding. Sebab itu, saya tidak berani untuk kasasi ke Mahkamah Agung. Saya menerima putusan ini. Apalagi yang mau dikatakan. Kalau banding dalam urusan Tipikor ini berbahaya, bisa berlipatlipat hukumannya dan harus mengeluarkan banyak uang. Ada penegak hukum yang tidak jujur."

Dengan demikian, adalah suatu keniscayaan pula bagi institusi agama Islam untuk berperan, berfungsi dan bertanggung jawab melakukan penerjemahan Al-Quran mengenai "mencuri," "menggelapkan dan "mengambil barang milik orang lain" dalam hubungan dengan perbuatan Tipikor, demi memperjuangkan kebenaran dan keadilan. Selain itu, peran, fungsi dan tanggung jawab institusi agama terhadap rasa kebenaran dan keadilan sangat diperlukan bagi para oknum jaksa, polisi, hakim, pengacara dan media 
masa/publik agar dalam menjalankan tugas kenegaraan mereka tetap memiliki hati nurani yang murni, sebab akibat dari setiap tuntutan dan keputusan hukum yang berkekuatan hukum tetap (inkraag) tidak hanya berdampak bagi sang terdakwa, melainkan juga terhadap masa depan, harga diri dan marwahnya sebagai seorang dan keluarganya yang beriman dan bertaqwa kepada Allah SWT.

\section{Peran, Fungsi dan Tanggungjawab Institusi Agama mendampingi pelaku perbuatan Tipikor}

Setelah para informan yang beragama Kristen Protestan itu divonis karena perbuatan Tipikor, petugas institusi agama mereka (pendeta, penatua, diaken, aktivis pelayanan gereja) datang berkunjung dan menemui, mendoakan dan menasihati mereka untuk tabah, bertekun, beriman dan tetap berpengharapan menunggu proses peradilan di Rumah Tahanan Negara serta menjalani masa binaan di LAPAS ini. Namun hal itu dilakukan secara insidental.

Berdasarkan kunjungan dan doa yang dilakukan oleh para pendeta, penatua, diaken, aktivis pelayanan gereja, mereka merasa tertolong untuk rela menjalani hukuman sekaligus menyadari dan insyaf atas perbuatan mereka dan berjanji jika mereka bekerja kembali (direhabilitasi) sebagai Aparatur Sipil Negara, maka mereka akan semakin berhatihati dalam melaksanakan tugas pengabdiannya. Peran, fungsi dan tanggung jawab institusi agama diperlukan terutama yang bersentuhan dengan proses-proses penyelidikan, penyidikan, penuntutan dan penjatuhan vonis terhadap para pelaku perbuatan Tipikor yang dituduhkan kepada umatnya. Banyak yang terjerat kasus Tipikor, namun tidak ada program selain hanya berkhotbah dan dukungan doa kepada mereka. Tidak ada sosialisasi langsung kepada masing-masing warga binaan sesuai dengan kasus-kasus hukum yang dihadapi mereka.

Harapan mereka ke masa depan adalah pimpinan institusi agama Kristen Protestan (para pendeta, penatua, diaken, aktivis pelayanan gereja) secara rutin melakukan sosialisasi atau pelatihan anti korupsi baik di kalangan orang dewasa, maupun terutama di kalangan generasi muda (anak, remaja dan pemuda) agar umat semakin berhati-hati dalam melaksanakan tugas sehingga tidak terjebak dalam kasus-kasus Tipikor seperti yang mereka alami. Tentang hal ini, Ibu E.M., berpendapat

Harapan saya ke depan adalah pimpinan gereja dan/atau para pendeta melakukan sosialisasi atau pelatihan anti korupsi baik di kalangan orang dewasa, maupun terutama di kalangan generasi muda (anak, remaja dan pemuda), supaya umat semakin berhati-hati dalam melaksanakan tugas dan tidak terjebak dalam kasus-kasus Tipikor seperti yang saya alami. Saya mengusulkan agar para pendeta rajin mengajarkan perbuatan-perbuatan yang tidak koruptif. Sekaligus melakukan pendampingan dan dukungan moral bagi umat terutama pada saat-saat menjalani proses penyelidikan, penuntutan dan peradilan, serta ketika berada di LAPAS. Sebab selama menjalani masa binaan, saya dan para warga binaan membutuhkan pendampingan dan dukungan doa bagi kami, sekaligus kepada keluarga kami yang berada di rumah. ${ }^{38}$

Pendapat yang sama juga ditambahkan pula oleh Ibu F.L.,

Hendaknya pimpinan gereja gencar melakukan sosialisasi mengenai Undangundang Tipikor, karena sosialisasi ini kurang dilakukan oleh pemerintah. Dengan begitu, umat semakin berhati-hati dalam melaksanakan tugas. Sebab kesalahan administratif pun bisa diklasifikasikan sebagai perbuatan Tipikor. Saya merasa sulit untuk membuktikan bahwa saya tidak punya niat hati untuk melakukan perbuatan Tipikor karena kurang didukung oleh administrasi keuangan/perbendaharaan yang lengkap. Umat pun tidak terjebak dalam kasus-kasus Tipikor seperti yang saya alami. Saya mengusulkan agar para warga binaan yang divonis melakukan

38 E.M (Warga Binaan, kasus Tipikor APBD Hukuman Inkraag 1,2 Tahun). 
perbuatan Tipikor yang seagama dengan saya dikelompokkan secara khusus dalam pembinaan agama di LAPAS ini, sehingga potensi kami dapat didayagunakan untuk saling memberdayakan. Selain itu, pelayanan gereja tidak menjauhkan diri dari kami, sebab tidak semua warga binaan dalam kasus ini memiliki niat hati untuk melakukan perbuatan Tipikor yang melawan hukum."39

Dari pendapat para informan kunci ini, nampaklah bahwa mereka dalam menghadapi konsekuensi hukuman, sejelek apapun menjadi lebih berserah diri kepada Tuhan. Sebab proses binaan di LAPAS ini menumbuhkan pemahaman iman bahwa yang mereka alami tidak lepas dari kehendak Tuhan, atau cara Tuhan untuk menguji dan menegur, membelajarkan diri mereka berpikir positif. Dengan keadaan ini, mereka berkesempatan untuk selalu bertemu Tuhan secara pribadi, ketika selama ini karena tuntutan pekerjaan menyebabkan pribadi mereka jauh dari Tuhan. Sekaligus menjadi momen untuk memperbaiki diri.

Selain itu, mereka mendambakan peran, fungsi dan tanggung jawab institusi agama untuk mempersiapkan umat di lingkungan tempat mereka bermukim untuk siap menerima mereka dengan rasa empati ketika mereka selesai menjalani masa binaan di LAPAS ini. Sebab tidak semua warga binaan kasus Tipikor ini memiliki niat hati untuk melakukan perbuatan Tipikor yang melawan hukum. Pendampingan pimpinan institusi agama itu penting agar mereka sendiri dapat menyelenggarakan doa dan saling menguatkan yang dipimpin secara bergiliran oleh penghuni setiap kamar dalam LAPAS ini. Selain itu, agar warga binaan tidak jatuh sakit atau

39 F.L (Warga Binaan kasus Tipikor Pencatatan Uang Masuk dan Keluar Anggaran Belanja Kebutuhan Pemilihan Umum Kepala Daerah Kota Ambon Tahun 2011 yang tidak dapat dipertanggungjawabkan pada Tahun 2012. Putusan Inkraag pada tahun 2015, Hukuman - 1, 2 tahun) kesehatan menurun karena beban psikologis yang mereka hadapi.

Setelah para informan yang beragama Kristen Katholik ini divonis karena melakukan perbuatan Tipikor dan menjalani masa binaan di LAPAS, barulah saudara mereka menginformasikan kepada mereka bahwa pimpinan institusi agama mereka (pastor, frater dan zuster) menyebutkan nama mereka dalam doa saat ibadah misa berlangsung. Meskipun doa yang disampaikan itu bersifat insidental, perhatian institusi agama mereka terhadap permasalahan hidup mereka telah terwujud. Namun dambaan mereka adalah kunjungan kepada mereka. Menurut Ibu A.H.M,

Sering saya menjadi sedih ketika menyaksikan tokoh-tokoh agama lain berkunjung, baik pada waktu beribadah, menyampaikan khotbah dan nasihat yang membangkitkan harapan hidup mereka. Meskipun nasihat-nasihat itu tidak langsung mengulas mengenai perbuatan Tipikor. Apalagi ketika saya mendengar suami saya telah menjalin hubungan cinta dan mempunyai anak dengan perempuan lain."

Dengan doa yang dilakukan oleh tokohtokoh agama yang lain, mereka merasa tertolong untuk menjalani hukuman dengan tidak berputus asa. Malahan mereka bisa belajar dan mampu berdoa serta memberikan nasihat kepada saudara mereka yang datang berkunjung dan berbagi permasalahan hidup kepada mereka.

Harapan mereka ke masa depan adalah pimpinan institusi agama mereka dalam hal ini uskup, pastor, frater, zuster secara rutin datang berkunjung untuk melayani dan melakukan pendampingan di LAPAS ini, serta dapat menjelaskan kepada mereka hubungan di antara perbuatan Tipikor, Kriminal Umum dan Khusus lainnya dengan ajaran agama Kristen Katholik.

Selanjutnya, menurut informan kunci yang beragama Islam, setelah mereka divonis kasus Tipikor dan menjadi warga binaan di LAPAS Kelas IIa Ambon ini, mereka sama sekali tidak memperoleh perhatian apalagi pendampingan dari institusi agama Islam, seperti 
MUI, NU, Muhammadiyah, Lembaga Dakwah, IAIN dan Universitas Darussalam yang punya kegiatan dakwah atau pembinaan di sini. Padahal ada bagian Bina Mental di LAPAS Kelas IIa ini bisa bekerjasama dengan institusi agama Islam tersebut.Selanjutnya ditambahkan oleh Bapak H.T.,

Saya berharap organisasi masyarakat (Ormas) Islam harus memberi perhatian pembinaan terhadap warga binaan di LAPAS ini. Juga materi khutbah atau dakwah harus menyentuh jiwa, agar kami sebagai warga binaan sabar dan bisa meningkatkan keimanan dan ketaqwaan."40

Peran, fungsi dan tanggung jawab institusi agama Islam yang dialami warga binaan ini hanya pada Hari Raya dan Hari Jum'at saja. Itu pun bukan program institusi agama Islam. Warga binaan ini tidak merasakan peran, fungsi dan tanggung jawab institusi agama Islam secara rutin berupa kegiatan untuk warga binaan di sini. Para ustaz yang melakukan pembinaan di sini lebih berupa peran pribadi. Mereka dari Pembinaan Mental Kodam XVI Pattimura, yaitu ustaz Haji Ma'ruf, tetapi itupun hanya satu kali.

Selain itu, pola dakwah atau ceramahnya kurang menyentuh bahkan membuat warga binaan sakit hati. Dengan demikian dapat dianalisis bahwa mereka semakin diyakinkan bahwa kebenaran dan keadilan pasti datang dan mereka pasti memetik hasil dari ibadah dan ketaqwaan mereka. Pengalaman sebagai warga binaan adalah merasa semakin dekat kepada Allah SWT. Hal ini nampak dari diri mereka yang menjalankan doa lima waktu setiap hari secara kontinyu. Sebuah kegiatan yang tidak mereka lakukan sebelum berada di LAPAS ini.

Mereka juga berpendapat bahwa sampai saat ini mereka belum tahu apakah ada atau tidak program institusi agama Islam untuk mengeliminasi perbuatan Tipikor. Memang pada hari raya dan sembahyang Jum'at ada khotbah dan pada bulan puasa ada ceramah.

40 J.K (Warga Binaan kasus Tipikor Dana Tapal Batas antara Kabupaten Seram Bagian Barat dan Maluku Tengah).
Juga waktu Halal bi Halal, dan kegiatan Majelis Ta'lim. Walaupun materinya bersifat umum, tidak fokus ke korupsi. Bagian pembinaan di LAPAS ini yang meminta da'i, yang kebetulan berasal dari dosen IAIN dan Universitas Darussalam. Mereka hadir sebagai pribadi, bukan mewakili institusi agama Islam. Menurut informan kunci, yang lebih parah lagi adalah masjid di LAPAS ini hanya dibuka pada waktu shalat Dzuhur dan Ashar. Sedangkan pada waktu shalat yang lain, masjid tersebut ditutup, sehingga pembinaan tidak bisa berlangsung di waktu-waktu tersebut.

\section{Institusi Agama kurang berfungsi dan berperan dalam upaya pencegahan dan pemberantasan korusi di Maluku}

Bila data ini dianalisis, ternyata bahwa secara umum, peran, fungsi dan tanggung jawab institusi keagamaan di Maluku, baik Majelis Ulama Indonesia (MUI) wilayah Maluku (Islam), Sinode Gereja Protestan Maluku (GPM, Protestan), dan Keuskupan Amboina (Katolik), kurang melaksanakan peran, fungsi dan tanggung jawabnya dalam upaya pemberantasan tindak pidana korupsi. Institusi keagamaan di Maluku, baik MUI wilayah Maluku (Islam), Sinode GPM (Protestan) maupun Keuskupan Amboina (Katolik), belum memiliki perencanaan dan program-program yang strategis, sistemik, komprehensif, terukur dan berkesinambungan, baik untuk melakukan pencegahan maupun pendampingan kepada umatnya yang melakukan perbuatan Tipikor. Institusi-institusi keagamaan ini kurang mengajarkan nilai-nilai agama masing-masing yang anti-korupsi kepada umatnya. Institusi-institusi keagamaan ini juga kurang bahkan belum mendampingi umatnya yang telah menjadi warga binaan LAPAS Kelas IIa Ambon, karena terkait dengan kasus Tipikor. Sangat jarang para pemimpin institusi agama dimaksud (rohaniawan) datang mengunjungi dan mendampingi mereka untuk memberikan nasihat dan penguatan iman dan spiritual bagi mereka sehingga mereka bisa menjalani keterhukuman mereka terebut dengan sabar dan tawakal. Kalaupun ada kunjungan para rohaniawan 
tersebut, hanyalah insidental, tidak secara terencana, tersistem dan berkesinambungan. Para rohaniawan yang datang ke LAPAS ini, hanya memberikan siraman rohani melalui khutbah dalam ibadah atau nasihat keagamaan secara umum, dan tidak secara khusus mendampingi mereka yang tersangkut kasus Tipikor. Warga binaan yang tersangkut kasus Tipikor ini, sangat mengharapkan rohaniawan dapat mendampingi mereka dan memberi penguatan rohani kepada mereka atas persoalan yang mereka hadapi secara khusus, walaupun kenyataannya harapan tersebut terwujud secara insidental.

Tentang peran, fungsi dan tanggungjawab institusi Agama Kristen mendampingi pelaku perbuatan Tipikor dan mencegah/memberantas Tipikor, menurut Pendeta A.J.S. Werinussa selaku Ketua Sinode Gereja Protestan Maluku (GPM),

Agama Kristen melarang dan menolak perilaku korupsi. Alkitab dengan tegas mengajarkan agar jangan mencuri, ataupun jangan menerima suap/sogok. Gereja mengajarkan warga gereja agar jangan melakukan korupsi karena bertentangan dengan kehendak Allah di dalam Alkitab. Ajaran ini disampaikan di dalam khotbahkhotbah minggu atau juga dalam ibadahibadah lainnya. Namun hal ini disampaikan hanya secara insidental, karena GPM memiliki tema-tema bulanan/minggguan dalam penyampaian khotbah/renungan. Memang, ada gagasan gereja untuk menghasilkan ajaran gereja yang melarang korupsi dalam bentuk buku pedoman atau bahan bacaan. $^{41}$

Pandangan dan sikap agama Kristen, khususnya Agama Kristen Protestan, dalam hal ini Gereja Protestan Maluku adalah jelas dan tegas terhadap perilaku Tipikor. Korupsi difahami sebagai kejahatan terhadap kemanusiaan dan terhadap Tuhan serta alam lingkungan, ciptaan Tuhan. Malahan secara

${ }^{41}$ A.J.S. Werinussa (Ketua Sinode Gereja Protestan Maluku), Wawancara oleh Henky H Hetharia, kantor Sinode GPM Ambon, tanggal 24 Oktober 2016 pukul 09.00 WIT. tegas dinyatakan bahwa korupsi adalah pemberontakan terhadap Tuhan. Karena korupsi adalah mengambil yang bukan haknya sebagaimana telah ditetapkan oleh Tuhan melalui jabatan yang dianugerahkan-Nya kepada manusia dalam masyarakat. Perilaku dan tindakan koruptor merugikan hak-hak orang lain. Sebab itu, GPM melalui LPJ ini mengajarkan warga dan pelayannya untuk mencegah perbuatan tindak pidana korupsi yang menyalahgunakan jabatan dan wewenang mereka, baik dalam masyarakat maupun dalam institusi gereja sendiri. Hal itu dilakukan dalam bentuk penyampaian Kotbah, Renungan, Penelaahan Alkitab, Diskusi, Meditasi dan Ceramah dalam setiap kegiatan ibadah (pada hari Minggu dan hari-hari Ibadah warga dan pelayan GPM, mulai Selasa sampai dengan hari Sabtu). Selain itu, pengajaran anti korupsi juga diajarkan melalui pembinaan Keluarga dengan menggunakan Santapan Harian Keluarga dan melalui pembinaan Warga Gereja Profesi dengan menggunakan Santapan Harian Warga Gereja Profesi dan pelatihan-pelatihan, pembinaan spiritualitas bagi mereka dan para pelayan khusus GPM (pendeta, penatua dan diaken). Kegiatan pelatihan dan pembinaan spiritualitas itu dilakukan atas inisiatif para warga gereja profesi dan pelayan khusus GPM tersebut. Dengan begitu, para pelayan khusus GPM diharapkan dapat berfungsi sebagai satuan tugas antikorupsi. Juga dalam bentuk penyebaran brosur antikorupsi untuk para warga GPM yang menjadi politisi. Amat disayangkan bahwa kegiatan pelatihan dan pembinaan ini tidak merata berlangsung di seluruh wilayah pelayanan GPM yang meliputi Provinsi Maluku dan Maluku Utara. Sebab tidak seluruh warga dan pelayan GPM berinisiatif melakukan kegiatan ini. Malahan pelatihan dan pembinaan spiritualitas ini tidak berlangsung secara kontinyu. ${ }^{42}$

42 A. Iwamony (Direktur Lembaga Pembinaan GPM), Wawancara oleh Henky H Hetharia, kantor LPJ GPM Ambon, tanggal 24 Oktober 2016 pukul 12.00 WIT. 
Dalam pendampingan terhadap pelaku Tipikor di LAPAS, Sinode GPM belum melakukan pendampingan secara sistemik, holistik, komprehensif, kontinyu, terukur dan transformatif. Seluruh langkah pendampingan masih bersifat insidental, parsial dan fragmentaris. Selain materi pelatihan dan pembinaan yang telah dikemukakan sebelumnya, belum ada program pemberantasan korupsi atau antikorupsi yang dilakukan secara institusional oleh pimpinan GPM. Belum ada program khusus yang berkaitan dengan sosialisasi Undang-Undangan RI Nomor 31 tahun 1999 dan UU RI Nomor 20 tahun 2001 serta berbagai Peraturan Pemerintah yang menjadi jabarannya. Program yang bersifat pembinaan spiritualitas pencegahan tindak pidana korupsi dilaksanakan dalam tempattempat ibadah, rumah keluarga, dan rumah yang menjadi tempat pertemuan warga dan pelayan khusus GPM. Meskipun dalam tahun 2015 kami melakukan tiga kali pendampingan di LAPAS Kelas IIa Ambon, namun sampai saat ini kami belum pernah diukur tingkat keberhasilan program pembinaan spiritualitas ini. Dari meningkatnya jumlah warga binaan pelaku tindak pidana korupsi, dapat diasumsikan bahwa program pembinaan ini kurang memiliki pengaruh positif dalam kehidupan warga dan pelayan khusus GPM. Sebab itu, baik Ketua Sinode maupun Direktur LPJ GPM sepakat bahwa diperlukan adanya program pencegahan dan pemberantasan korupsi yang dilakukan secara lintasagama, baik di antara Kristen Protestan dengan Katolik, maupun di antara Kristen Protestan dengan Agama Islam dan agama-agama lainnya. Selama ini, program lintasagama lebih berfokus pada pemahaman, kesadaran, penghayatan dan perilaku warga terhadap kemajemukan dan keserasian sosial dan belum terarah kepada pencegahan tindak pida korupsi.

Pandangan ini dinyatakan pula oleh $\mathrm{H}$. Idroes Tukan, Ketua MUI Provinsi Maluku, bahwa:

"Memang belum ada program tertulis lintas agama, tapi kami sudah punya komitmen untuk semua agama di Maluku ini untuk sama-sama memerangi korupsi, narkoba, asusila, teroris dsbnya. Walau pun belum ada kegiatan bersama, tetapi dari komitmen ini, saya yakin akan berdampak sangat positif bagi perkembangan masyarakat di Maluku." 43

Secara umum, para warga binaan yang terkait masalah Tipikor ini baik yang beragama Islam, Kristen Protestan maupun Katolik, mengakui bahwa bukan hanya mereka yang berada di LAPAS yang tidak didampingi, tetapi juga keluarga (isteri/suami dan anak-anak mereka) jarang didampingi dan dikuatkan oleh para pimpinan institusi agama. Padahal keluarga mereka pun mengalami beban psikologi akibat hukuman yang dialami para informan karena kasus korupsi, sehingga membutuhkan penguatan dari para rohaniawan. Keluarga juga mengalami sanksi sosial dengan adanya anggota keluarga mereka yang terjerat hukuman Tipikor. Tipikor dipandang oleh masyarakat sebagai suatu perbuatan yang tercela, sehingga keluarga mereka sering dikucilkan dan menjadi objek pergunjingan dalam masyarakat. Dalam realitas ini, mereka membutuhkan penguatan iman dan rohani dari para rohaniawan. Mereka mendapatkan pendampingan dan penguatan dari institusi agama mereka (para rohaniawan) secara insidental. Padahal, beberapa informan kunci mengakui bahwa ketika mereka belum terkait kasus Tipikor dan masih memiliki posisiposisi penting di masyarakat atau di birokrasi pemerintahan, para informan kunci ini sering kali menjadi tumpuan institusi agama dalam memenuhi kebutuhan-kebutuhan institusi agama. Para informan kunci ini sering dimintai bantuan oleh institusi agama, baik materi, jasa maupun kebutuhan lainnya. Namun ketika mereka terkait kasus Tipikor, mereka mengakui bahwa baik mereka maupun keluarga mereka terabaikan oleh institusi agama. Para pemuka agama tidak lagi mendampingi dan menguatkan mereka dalam menghadapi kasus Tipikor. Tidak jarang

\footnotetext{
43 Idroes Tukan (Ketua MUI Provinsi Maluku), Wawancara oleh Henky H Hetharia, Kantor DPW MUI Maluku , tanggal 29 November 2016 pukul 10.00 WIT.
} 
mereka dipandang sebagai orang-orang berdosa.

Bila data ini dianalisis, ternyata peran, fungsi dan tanggung jawab institusi keagamaan (Kristen Protestan, Katholik dan Islam) di Provinsi Maluku belum berlangsung sebagaimana yang diharapkan oleh warga binaan kasus Tipikor. Sebab tindak pidana korupsi lahir dari rasa kebutuhan (corruption out of need) dan keserakahan (corruption out of greed). Memang, ketiga institusi agama secara normatif dogmatis mengajarkan "jangan mencuri" namun kritik teks atau penerjemahan teks ke dalam realitas konteks di Maluku belum memberikan gambaran utuh mengenai "jangan mencuri" yang mencakup juga "jangan korupsi." Peran institusi keagamaan tidak hanya pada aras pencegahan, melainkan juga pada aras advokasi. Karena proses hukum terhadap kasus-kasus Tipikor tidak semuanya berlangsung secara adil dan benar. Proses hukum terhadap Tipikor dengan keputusan vonis tanpa alat bukti yang valid sangat mengenaskan dan menciderai rasa keadilan. Peranan institusi agama melalui para ulama (pendeta, pastor, ustadz, kiyai, juru dakwah), dan para pimpinan organisasi masyarakat keagamaan di Maluku tidak hanya pada tahap preventif dan kuratif terhadap pelaku Tipikor, tetapi juga terhadap para pimpinan LSM pegiat anti korupsi, wartawan, penasihat hukum/pengacara, jaksa, polisi dan hakim yang berkelindan menggiring seseorang yang bukan pelaku menjadi terhukum Tipikor tanpa alat-alat bukti yang akurat. Semangat anti korupsi dijunjung tinggi oleh ajaran agama-agama di Maluku dan para ulamanya. Namun semangat itu harus diwujudkan secara adil dan benar sesuai prinsip, kaidah dan norma hukum. Bukan karena kepentingan politis atau dorongan syahwat kekuasaan. Dalam hal ini, peranan institusi agama-agama di Maluku, baik melalui peranan institusi maupun para pemimpin, ulama (pendeta, pastor, uztad, kyai, juru dakwah), dan umatnya untuk mencegah korupsi menjadi berbeda dari peranan kepolisian, kejaksaan, kehakiman dan lembaga pendidikan antikorupsi. Dalam hal ini, institusi agama-agama di Maluku berperan untuk melakukan program lintasagama mencegah korupsi yang diimplementasikan secara sinergis terhadap masing-masing umatnya. Program lintasagama ini dapat melahirkan perumusan bersama kurikulum dan bahan ajar pendidikan agama anti korupsi yang mengandung pembelajaran nilai-nilai hidup Ugahari (bersahaja) dan Thaharah (bersuci).

\section{SIMPULAN}

Peran, fungsi dan tanggung jawab institusi keagamaan (Islam, Kristen Protestan, Katholik) disadari sangat strategis dalam mendampingi para warga binaan kasus Tipikor dengan perencanaan yang strategis, sistemik, komprehensif, terukur, sinergis dan berkesinambungan, baik untuk melakukan pencegahan maupun pendampingan kepada umatnya yang terjerat kasus Tipikor. Peran, fungsi dan tanggung jawab institusi keagamaan (Kristen Protestan, Katholik dan Islam) itu bukan hanya sebelum umat dan pimpinan umat terjerat kasus Tipikor, tetapi juga pada saat menjalani masa binaan di LAPAS. Malahan yang sangat kritis dan strategis adalah pada waktu menjalani tahap-tahap penyelidikan, penyidikan, penuntutan, peradilan dan penjatuhan vonis terhadap mereka yang terjerat kasus Tipikor. Peran, fungsi dan tanggung jawab institusi agama ini tidak hanya ditujukan kepada umatnya yang didakwa kasus Tipikor, tetapi juga ditujukan kepada para oknum jaksa, polisi, pengacara, hakim, BPK/BPKP dan wartawan yang berkelindan menangani kasus Tipikor tersebut.

Peran, fungsi dan tanggung jawab institusi keagamaan di Maluku, yaitu Majelis Ulama Indonesia (MUI) wilayah Maluku (Islam), Sinode Gereja Protestan Maluku (Protestan), dan Keuskupan Amboina (Katolik), ternyata sangat lemah dalam upaya pemberantasan tindak pidana korupsi di Maluku. Kelemahan Institusi-institusi Agama di Maluku ini, baik dari segi konsep ajaran, pengorganisasian maupun kapasitas dan sense of calling pada diri para ulama/pendeta/pastor sebagai berikut: (1) Belum berperan dan berfungsi secara baik dalam membina dan memperkuat 
spiritualitas dan etik-moral umatnya masingmasing, yang dapat mencegah terjadinya Tipikor oleh warganya termasuk mereka yang berprofesi sebagai oknum-oknum penyidik, penuntut, pengadil, pembela, pekerja media dan pegiat lembaga swadaya masyarakat yang menangani kasus Tipikor; (2) Ketiga institusi agama di Maluku ini (MUI, Sinode GPM dan Keuskupan Amboina) belum memiliki suatu perencanaan yang strategis, sistemik, komprehensif, terukur, sinergis dan berkesinambungan dalam upaya pencegahan tindakan korupsi secara institusional dan lintas institusional keagamaan; (3) Sangat jarang dilakukan siraman rohani dan pembinaan moral dari tokoh-tokoh agama, maupun bahanbahan pengajaran tertulis dari institusi agama bagi umatnya tentang nilai-nilai agama yang menentang korupsi; (4) Tanggung jawab institusi keagamaan untuk merumuskan dan melaksanakan sosialisasi Undang-Undang dan berbagai Peraturan Pemerintah yang berkaitan dengan pemberantasan korupsi bagi umatnya juga sangat jarang dilakukan, kesadaran antikorupsi masih lemah; (5) Tanggung jawab institusi keagamaan di Maluku untuk mereinterpretasi teks-teks kitab suci yang menentang tindakan korupsi belum dilakukan secara utuh; (6) Teks-teks kitab suci yang antikorupsi tidak disiarkan dan diajarkan oleh institusi keagamaan, sehingga umat kurang dibekali dengan nilai-nilai moral agama antikorupsi yang dapat mencegah terjadinya Tipikor di kalangan umat beragama di Maluku; (7) Peran, fungsi dan tanggung jawab institusi keagamaan di Maluku, dalam hal ini, Majelis Ulama Indonesia (MUI) wilayah Maluku (Islam), Sinode Gereja Protestan Maluku (Protestan), dan Keuskupan Amboina (Katolik) dalam mendampingi warga binaan di LAPAS yang terkait kasus Tipikor, ternyata sangat minim dan lemah, kalaupun ada sifatnya hanya insidential, tidak secara tersistem, komprehensif, terukur dan berkesinambungan; (8) Harapan warga binaan yang tersangkut kasus Tipikor, terhadap pendampingan dan penguatan rohani/spiritual dari institusi agama masing-masing, ternyata belum intens terwujud. Mereka sebagai warga binaan kurang mendapat pendampingan dan penguatan rohani terkait dengan kasus yang mereka alami, hanyalah penguatan rohani yang sifatnya umum; (9) Harapan keluarga (suami/isteri dan anak-anak) dari warga binaan yang tersangkut kasus Tipikor, terhadap pendampingan dan penguatan rohani/ spiritual dari institusi agama masing-masing, ternyata belum terwujud pula secara intensif. Padahal, warga binaan ini maupun keluarga mereka mengharapkan dukungan doa dan moril dari para tokoh agama, bukan hanya secara personal tetapi juga institusional dalam menghadapi kasus Tipikor ini; dan (10) Peran institusi keagamaan di Maluku dalam menghadapi kasus Tipikor tidak hanya ketika seseorang telah ditindak oleh para penegak hukum, melainkan terutama dalam memberdayakan secara intelektual, moral-etik (akhlak), spiritual (iman dan taqwa), baik umatnya yang bergerak dalam berbagai kegiatan pembangunan, bisnis dan finansial maupun terhadap oknum-oknum penegak hukum (polisi, jaksa, hakim, pengacara), pekerja media dan pegiat lembaga anti rasuah ini yang berkelindan dalam penanganan kasuskasus Tipikor. Peran ini pula yang membedakan institusi keagamaan dari pada institusi pendidikan.

\section{UCAPAN TERIMA KASIH}

Artikel ini diolah dari hasil penelitian yang telah dilakukan penulis pada tahun 2016, yang didanai oleh Kementerian Riset, Teknologi dan Pendidikan Tinggi Republik Indonesia (Kemenristekdikti RI) melalui skim Hibah Penelitian Fundamental Kemenristekdikti RI, 2016. Sebab itu, penulis menyampaikan ucapan terima kasih yang tulus kepada pihak Kemenristekdikti RI yang telah mendukung penelitian dan penulisan artikel ini melalui penyediaan dana penelitian yang sangat membantu penulis. Semoga penelitian dan penulisan ini bermanfaat bagi pihak-pihak terkait dan terlebih bagi pengembangan keilmuan di Indonesia.

Penulis juga hendak menyampaikan terima kasih dan penghargaan yang tulus kepada pihak LAPAS Kelas IIa Ambon, yang telah 
memberikan kesempatan kepada penulis untuk melakukan penelitian (wawancara) dengan warga binaan yang terkait dengan kasus Tipikor sebagai informan kunci. Tanpa bantuan dan kerja sama yang baik dari seluruh pihak di LAPAS Kelas IIa Ambon, penelitian dan penulisan artikel ini tidak dapat dilakukan dengan baik.

Penulis menyadari bahwa tanpa peran aktif dari warga binaan di LAPAS Kelas IIa Ambon yang terkait kasus Tipikor, yang menjadi informan kunci dalam penelitian ini, maka seluruh penelitian dan penulisan artikel ini tidak mungkin akan terselesaikan. Sebab itu, dengan penghargaan yang tulus, penulis menyampaikan terima kasih kepada para informan kunci dimaksud, dan dengan rasa empati yang dalam, penulis tetap doakan semoga Tuhan Yang Maha Kuasa memberi kekuatan kepada mereka dan keluarga mereka untuk menjalani realitas hidup ini dengan penuh penyerahan diri kepada-Nya.

\section{DAFTAR PUSTAKA}

Alatas. Korupsi, Sifat, Sebab dan Fungsi. Jakarta: LP3ES, 1987.

_. Sosiologi Korupsi. Jakarta: LP3ES, 1981.

Anwary, S. Quo Vadis Pemberantasan Korupsi Di Indonesia. Jakarta: ISEPSAMRA, 2005.

Borrong, Robert. Etika Politik Kristen. Jakarta: UPI STT Jakarta, 2006.

Casram, Casram. "Membangun Sikap Toleransi Beragama Dalam Masyarakat Plural." Wawasan: Jurnal Ilmiah Agama Dan Sosial Budaya 1, no. 2 (2016): 187-98.

Departemen Pendidikan Nasional. Kamus Besar Bahasa Indonesia. Jakarta: Balai Pustaka, 2005.

Hetharia, Henky H, Samuel Julius Mailoa, and Elia Radianto. Agama Dan Perilaku Korupsi Di Provinsi Maluku. Ambon: Belum dipublikasikan, 2010.

Kejaksaan Tinggi Maluku. Laporan Bulanan Tindak Pidana Korupsi: Februari 2015. Ambon: Tidak dipublikasi, 2015.

Klitgaard, Robert. Membasmi Korupsi. Jakarta: Yayasan Obor Indonesia, 2001.
Rumahuru, Yance Zadrak. "Socio-Religious Movement of Religious Affiliated Student Organizations After Social Conflict in Ambon." Al-Albab 5, no. 2 (2016): 251-64.

Sekertariat Negara. "Sambutan Presiden RI Pada Pencanangan Gerakan Nasional Pemberantasan Korupsi , (Jakarta: Percetakan Negara RI, )." In Percepatan Pemberantasan Korupsi. Jakarta: Percetakan Negara RI, 2004.

Sugiyono, Bd. Memahami Penelitian Kualitatif. Bandung: Alfabeta, 2009.

Wijayanto, dan Zachrie Ridwan, eds. Korupsi Mengkorupsi Indonesia. Jakarta: PT Gramedia Pustaka Utama, 2009.

\section{WAWANCARA}

E.M (Warga Binaan, kasus Tipikor APBD Hukuman Inkraag 1,2 Tahun). wawancara oleh Henky H Hetharia, Kantor LAPAS Kelas II a di Ambon. tanggal 21 Mei 2016 pukul 11.00 WIT.

Y.P (Warga Binaan, kasus Tipikor Jaminan Kesehatan Masyarakat Tahun 2014 Hukuman Inkraag 1,2 Tahun). wawancara oleh Henky H Hetharia. Kantor LAPAS Kelas II a Ambon. tanggal 23 Mei 2016 pukul 12.00 WIT.

L.B (Warga Binaan, kasus Tipikor Uang Untuk dipertanggungjawabkan Provinsi Maluku - Hukuman Inkraag 5 Tahun). wawancara oleh Henky H Hetharia. Kantor LAPAS Kelas II a Ambon. tanggal $21 \mathrm{Mei}$ 2016 pukul 11.00 WIT.

Edm. S (Warga Binaan, kasus Tipikor Pengadaan perlengkapan alat-alat penerangan/lampu jalan dalam rangka MTQ Nasional 2012 di Ambon-Hukuman Inkraag 1 Tahun). wawancara oleh Henky $\mathrm{H}$ Hetharia. Kantor LAPAS Kelas II a Ambon. tanggal 18 Juni 2016 pukul 14.00 WIT.

F.M (Warga Binaan, kasus Tipikor Perjalanan Dinas Fiktif. - Hukuman Inkraag 2 Tahun). wawancara oleh Henky H Hetharia. Kantor LAPAS Kelas II a Ambon. tanggal 11 Juni 2016 pukul 11.00 WIT.

F.L (Warga Binaan kasus Tipikor Pencatatan Uang Masuk dan Keluar Anggaran Belanja 
Kebutuhan Pemilihan Umum Kepala Daerah Kota Ambon Tahun 2011 yang tidak dapat dipertanggungjawabkan pada Tahun 2012. Putusan Inkraag pada tahun 2015, Hukuman - 1, 2 tahun). wawancara oleh Henky H Hetharia. Kantor LAPAS Kelas II a Ambon. tanggal 23 Mei 2016 pukul 10.00 WIT.

N.H (Warga Binaan, kasus Tipikor Penggunaan Dana BOS dan Dana TIK. Hukuman Inkraag 1,5 Tahun). wawancara oleh Henky H Hetharia. Kantor LAPAS Kelas II a Ambon. tanggal 18 Mei 2016 pukul 12.00 WIT.

A.T (Warga Binaan, kasus Tipikor Pemanfaatan Dana Block Grant dalam bidang pendidikan dari Kemendiknas Hukuman Inkraag 2 Tahun dan 10 Bulan). wawancara oleh Henky H Hetharia. Kantor LAPAS Kelas II a Ambon. tangga Sabtu, 28 Mei 2016 pukul 14.00 WIT.

H.O (Warga Binaan, kasus Tipikor Dana Asuransi Anggota DPRD Kabupaten Maluku Tenggara -Hukuman Inkraag 1,6 Tahun). wawancara oleh Henky H Hetharia. Kantor LAPAS Kelas II a Ambon. tanggal 23 Mei 2016 pukul 14.00 WIT.

A.T (Warga Binaan, kasus Tipikor Pengadaan alat-alat kesehatan Laboratorium Provinsi. Maluku - Hukuman Inkraag 3 Tahun). wawancara oleh Henky H Hetharia. Kantor LAPAS Kelas II a Ambon. tanggal $30 \mathrm{Mei}$ 2016 pukul 14.00 WIT.

D. De Q (Warga Binaan, kasus Tipikor Proyek Pembangunan Mesjid Raya di Sanana Hukuman Inkraag 4 Tahun). wawancara oleh Henky H Hetharia. Kantor LAPAS Kelas II a Ambon. tanggal 18 Juni 2016 pukul 14.00 WIT.

E.S (Warga Binaan, kasus Tipikor Pengadaan Buku Perpustakaan Sekolah sesuai Dana Alokasi Khusus Tahun 2010 Kabupaten Maluku Tenggara Barat - Hukuman Inkraag 2,8 Tahun denda Rp.200 juta subsider 4 bulan penjara). wawancara oleh Henky H Hetharia. Kantor LAPAS Kelas II a Ambon. tanggal 28 Mei 2016 pukul 14.00 WIT.

F.B (Warga Binaan, kasus Tipikor Biaya
Sertifikat Prona di Kabupaten Maluku Tenggara Barat, Hukuman Inkraag 1 Tahun). wawancara oleh Henky $\mathrm{H}$ Hetharia. Kantor LAPAS Kelas II a Ambon, tanggal 11 Juni 2016 pukul 14.00 WIT.

A.H.H (Warga Binaan kasus Tipikor Penggelapan Uang Pajak Nasabah Hukuman Inkraag 11 Tahun). wawancara oleh Henky H Hetharia. Kantor LAPAS Kelas II a Ambon. tanggal 18 Juni 2016 pukul 14.00 WIT.

J.K (Warga Binaan kasus Tipikor Dana Tapal Batas antara Kabupaten Seram Bagian Barat dan Maluku Tengah). wawancara oleh Henky H Hetharia. Kantor LAPAS Kelas II a Ambon. tanggal 21 Mei 2016 pukul 14.00 WIT.

M.L (Warga Binaan, kasus Tipikor SPPD Hukuman Inkraag 2,8 Tahun). wawancara oleh Henky H Hetharia. Kantor LAPAS Kelas II a Ambon. tanggal 232016 pukul $12.00 \mathrm{WIT}$.

A.W (Warga Binaan, kasus Tipikor Dana Transportasi dan Akomodasi MTQ Tingkat Provinsi di Kabupaten Aru, 201.Hukuman Inkraag 1,5 Tahun). wawancara oleh Henky H Hetharia. Kantor LAPAS Kelas II a Ambon. tanggal 20 Mei 2016 pukul 10.00 WIT.

H.T (Warga Binaan, kasus Tipikor Dana Proyek di Politeknik Kesehatan). Wawancara oleh Henky H Hetharia. Kantor LAPAS Kelas II a Ambon. tanggal $30 \mathrm{Mei}$ 2016 pukul 10.00 WIT.

I.T (Warga Binaan, kasus Tipikor Dana Pengadaan Barang pada Dinas DPRD Kabupaten Seram Bagian Timur pada tahun anggaran 2011 - Hukuman Inkraag 1,7 Tahun). wawancara oleh Henky $\mathrm{H}$ Hetharia. Kantor LAPAS Kelas II a Ambon. tanggal 20 Juni 2016 pukul 10.00 WIT.

Werinussa, A.J.S. (Ketua Sinode Gereja Protestan Maluku). Wawancara oleh Henky H Hetharia. kantor Sinode GPM Ambon. tanggal 24 Oktober 2016 pukul 09.00 WIT. Pariama, W.B. (Wakil Ketua Sinode GPM). Wawancara oleh Henky H Hetharia. kantor 
Sinode GPM Ambon. tanggal 24 Oktober 2016 pukul 11.00 WIT.

Tukan, Idroes (Ketua MUI Provinsi Maluku).

Wawancara oleh Henky H Hetharia. Kantor

DPW MUI Maluku. tanggal 29 November

2016 pukul 10.00 WIT.

Iwamony, A. (Direktur Lembaga Pembinaan
GPM). Wawancara oleh Henky H Hetharia. kantor LPJ GPM Ambon. tanggal 24 Oktober 2016 pukul 12.00 WIT. 